\title{
Analysis of Brand Image and Online Consumer Reviews on Consumer Loyalty
}

\author{
Lisnawati $^{1 *}$, Asep Muhamad Ramdan², Dicky Jhoansyah ${ }^{3}$ \\ ${ }^{123}$ Muhammadiyah Sukabumi University, Sukabumi \\ *Email Corespondent : lisna026@ummi.ac.id
}

\begin{abstract}
This study aims to determine the effect of the brand image variable (X1) and online consumer review on consumer loyalty $(Y)$. The method used in this research is descriptive and associative methods using a quantitative approach, the sample used is 150 respondents to consumers of Nature Republic Aloe Vera $92 \%$ Soothing Gel in Sukabumi City which are distributed using googlefrom, and using probability sampling techniques using probability sampling. random sampling. The data analysis technique used is the multiple linear analysis technique, the Ttest and the F test. The results of this study indicate that the brand image variable (X1) has a positive and significant effect on the consumer loyalty variable $(Y)$ and the online consumer review variable (X2) also has a positive and significant effect on the consumer loyalty variable $(Y)$. The coefficient of determination test results showed a value of 0.516 which can be interpreted as the percentage of variables X1 and X2 which have a value of $51.6 \%$ and the remaining $48.4 \%$ which is influenced by other factors not examined in this study.
\end{abstract}

Keywords : Brand image, online consumer review, consumer loyalty

\begin{abstract}
Abstrak: Penelitian ini bertujuan untuk mengetahui pengaruh variabel citra merek (X1) dan review konsumen online terhadap loyalitas konsumen (Y). Metode yang digunakan dalam penelitian ini adalah metode deskriptif dan asosiatif dengan menggunakan pendekatan kuantitatif, sampel yang digunakan adalah 150 responden konsumen Nature Republic Aloe Vera 92\% Soothing Gel di Kota Sukabumi yang didistribusikan menggunakan googlefrom, dan menggunakan teknik probability sampling menggunakan probability sampling . pengambilan sampel secara acak. Teknik analisis data yang digunakan adalah teknik analisis linier berganda, uji $T$ dan uji F. Hasil penelitian ini menunjukkan bahwa variabel citra merek (X1) berpengaruh positif dan signifikan terhadap variabel loyalitas konsumen (Y) dan variabel ulasan konsumen online (X2) juga berpengaruh positif dan signifikan terhadap variabel loyalitas konsumen (Y). Hasil uji koefisien determinasi menunjukkan nilai sebesar 0,516 yang dapat diartikan sebagai persentase variabel $X 1$ dan X2 yang memiliki nilai sebesar 51,6\% dan sisanya 48,4\% yang dipengaruhi oleh faktor lain yang tidak diteliti dalam penelitian ini.
\end{abstract}

Keywords : Citra merek, ulasan konsumen online, loyalitas konsumen 


\section{INTRODUCTION}

The public's need for beauty and personal care products is currently increasing, which makes cosmetic and skincare producers more incessant to offer their products. This also does not rule out the possibility for adult men and women and adolescents who are currently very familiar with the cosmetic and skincare beauty products they use to meet their appearance needs, as according to(Biron, 2019) cosmetic growth in 2019 is worth around 4985 trillion rupiah, and the growth of cosmetics and skincare is estimated to increase by an average of around $4.38 \%$ (Shahbandeh, 2020). Judging from this, the growth of the cosmetic market is increasing day by day, which makes cosmetic products and skincare a very good opportunity for producers of a product.

In Indonesia, nowadays consumers are becoming smarter in choosing cosmetics and skincare, an image of a cosmetic or skincare brand can be a benchmark for consumers to purchase products. When viewed from the increasing number of illegal cosmetics found by BPOM with a value of 185.9 billion(Fajarta, 2020), no wonder consumers are becoming increasingly choosy about what to buy, one of the habits that are conscious or not in making a purchase usually consumers see the brand image of a product or service to be able to adjust to the desires of consumers(Aryatilandi et al., 2020). This is also in accordance with research(Rizaldi \& Hardini, 2018), in his research explains that a product or company must be able to maintain or improve the inherent brand image so that consumers are sure of their choice and not misdirected, and in this study reveals that brand image has a positive influence on consumer loyalty. The same thing is contained in(Octaviany et al., 2019) a consumer will easily give his loyalty if a brand has been highly trusted by the consumer.

One of the cosmetic and skincare product brands favored by consumers today is Nature Republic, where this company is a cosmetics and skincare manufacturer based in South Korea that offers various beauty products such as cosmetics, skincare, makeup equipment, and bodycare products (Naturerepublic, 2020).

In shopping for daily necessities, consumers in today's era are usually smarter in finding information about the goods they are going to buy. There are times when they look for reviews from several sources, such as getting information from social media, some reviews found on e-commerce, this method can make it easier for consumers to be more careful in buying and be a comparison between other products. Providing or digging up information about goods, both positive and negative, is beneficial for consumers so that consumers can accept each other and give trust according to what they have felt(Pirdaus et al., 2020). Judging from several e-commerce that sell Nature Republic products, especially the Aloe vera $92 \%$ soothing gel variant, many consumers give complaints and criticisms or bad reviews such as non-genuine products, products that cause skin problems and so on, this is what can cause taste doubt for consumers to buy and consumers who will return the product.

In this case, the problem that is often faced in maintaining consumer loyalty is the absence of the desire to repurchase products that they have bought before for several reasons, one of which is caused by a bad product image such as Nature Republic products due to the proliferation of illegal products that have been purchased. similar from the form of packaging to the brand, this can be a doubt for consumers who will buy a product which in the end consumers prefer another product, as well as negative reviews given by other consumers about the product can be a barrier and raise doubts for other consumers to buy the product.

Based on the phenomena that occurred above, the researchers were interested in analyzing the effect of brand image and online consumers review on consumer loyalty of Nature Republic aloe vera $92 \%$ soothing gel in Sukabumi City.

\section{LITERATURE REVIEW}

\section{Marketing}

In a company, marketing is very important for the survival of the company, where marketing is "an activity carried out by a person or company by buying and selling products or services to get benefits for both parties, namely producers can receive profit benefits and consumers are expected to. can meet the needs they expect " (Princess, 2017).

According to Sudaryono (2016: 42) Marketing is the process of planning and executing thoughts, pricing, promotion, and distribution of ideas, goods, services, organizations and events to create and maintain relationships that will satisfy both goals and individuals and bonds.

\section{Brand Image}

Kotler and Keller (2016: 330) states that "the extrinsic properties of the product or service, including the ways in which the brand attempts to meet customers' psychological or social needs" can be explained as an eccentric trait contained in a product or service that the company tries to fulfill both. it's the psychological needs as well as the social needs of its consumers.

Brand image can also be understood as an impression or brand image of a product or service, each of which has its own characteristics where consumers who buy a product or service not only provide goods or services but with the assessment or value contained in the company or brand (Ramadan, 2019; Tomida \& Satrio, 2016).

In this case, the image itself is a construct that must be owned or created by the company or the owner of a brand. The image that must be owned must be positive so that consumers can easily trust and get a place in the hearts of their consumers and can also easily compete in a more competitive market(Ramdan, 
Rahayu, Wibowo, et al., 2020). a positive brand image can not only easily compete in the market, but can be an added value that can increase profits for each of these companies.(Ramdan, Rahayu, Hurriyati, et al., 2020).

Brand image has several dimensions according to Aaker and Biel (in W, Pangestuti, \& Nuralam, 2018)These include: 1) Company image, which is a representation of a company according to consumer views, both positive and negative. 2) Product image, is an impression or assessment that exists on a product, usually the assessment comes from the consumer himself, where consumers who have had or tried the product feel how the quality provided is fulfilled or not, if the product criteria are in accordance with the consumer it will easily stick in the consumer's memory and vice versa 3) User image, which is a person's view of the image or impression that a consumer has who uses or consumes a product or service, such as being able to show social status and personality of the consumer.

Meanwhile, according to Kolter and Keller (in Cahyono, 2018), there are five dimensions that exist in the brand image variable, namely, brand identity, brand personality, brand association, communication behavior and brand benefits and advantages.

H1: There is an effect of brand image on consumer loyalty

\section{Online Consumer Review}

Online consumer review interpreted as a means by which consumers find information about the product or service they are going to buy, where consumer reviews are usually very informative and become a means of comparison between one product and another.

Online consumer review is one part of e-WOM which is used by consumers as a means of searching for information or instructions regarding an explanation of a product or service obtained via the internet, be it social media or consumer reviews found on various ecommerce platforms containing positive and negative reviews (Auliya et al., 2017; Kamila et al., 2019).

online consumer review is one of the tools or media for consumers in finding information about products or services and how the producer company can influence consumer purchasing decisions (Kanitra, 2018).

Online consumer review according to Goyette (in Marie \& Widodo, 2019) states that there are three dimensions described as follows: 1) intensity, which is the number of reviews given by consumers about a product and service on social media networks and other platforms, 2) Valance of opinion, namely one's affinity or interest in products and services on recommendations other people regarding reviews of goods or services they see on social media networks or others 3 ) content, is a review of a consumer who explains the various advantages or disadvantages of the goods or services they have used or consumed.

According to Bambaurer - Sachse and Mangold (in Angkiriwang, Susanto, \& Thio, 2018) There are no different dimensions, namely: 1) General persuasion 2) General credibility 3) Susceptibility to online product reviews

$\mathrm{H} 2$ : There is an effect of online consumer reviews on consumer loyalty

\section{Consumer Loyalty}

Consumer loyalty is one of the consumer behavior that is expected for any company, where this consumer behavior tends to provide benefits for the company.Consumer loyalty is a tendency to buy or reuse a product and service (Widyawati, 2006).

Own consumer loyalty according to Lovelock (in Ganyang, 2019)explained that consumer behavior can contribute more to companies where consumers of this type will easily make repurchases of products or services that they feel are according to their needs and wants, and loyal consumers will be able to easily recommend products and services that they already have. use or try on friends, family or others. However, not all consumer loyalty can contribute well, but if consumer expectations are not met, it is also influenced by other situations or circumstances, consumers can easily switch directions to products or services from other companies (Reza et al., 2020).

Consumer loyalty according to Griffin (Reza et al., 2020)There are four dimensions of consumer loyalty, namely: 1) Making repeated purchases, is a characteristic or condition that is very necessary for every company, where consumers will buy back goods or services in the company, 2) Make purchases between product lines or services, namely consumers will continue to make repeated purchases of products on a regular basis regardless of recommendations from other companies' products. 3) Referencing products to other people, this is an advertisement that consumers do to other consumers spontaneously because consumers feel appropriate and get what they expect. 4) Demonstrates immunity against competitors,

Based on the hypothesis contained in this study, the following is a paradigm model that the researcher will use, namely as: 


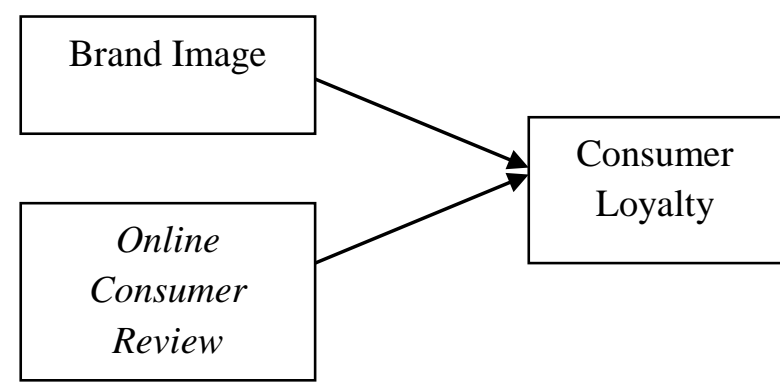

Figure 1. Research paradigm

\section{RESEARCH METHODS}

The method used in this research is descriptive and associative methods using quantitative approaches and the sample used in this research is as many as 150 respondents with the population in this study who are customers of Nature Republic Aloe Vera 92\% Soothing Gel products in Sukabumi City. The sampling technique was nonprobability sampling technique with purposive sampling.

In this study, the validity and reliability tests were used to test the questionnaire in order to obtain more accurate data. The data analysis technique used is by testing the coefficient of determination, multiple linear regression analysis and hypothesis testing with the $\mathrm{T}$ test (partial) and F test (simultaneous).

\section{RESULT AND DISCUSSION}

Following are the results obtained from a questionnaire from 150 respondents of Nature Republic consumers aloe vera $92 \%$ soothing gel in Sukabumi City. Data were processed using IBM SPSS Statistic version 24 software.

Validity test

Table 1. Validity Test Calculation Results

\begin{tabular}{ccccc}
\hline Variable & $\begin{array}{l}\text { R Value } \\
\text { Count }\end{array}$ & $\begin{array}{l}\text { R Value } \\
\text { Table }\end{array}$ & $\begin{array}{l}\text { Sig } \\
\text { value. }\end{array}$ & Status \\
\hline 0.648 & 0.159 & 0 & \\
& 0.640 & 0.159 & 0 & \\
& 0.702 & 0.159 & 0 & \\
X1 & 0.794 & 0.159 & 0 & Valid \\
& 0.769 & 0.159 & 0 & \\
& 0.796 & 0.159 & 0 & \\
& 0.713 & 0.159 & 0 &
\end{tabular}

\begin{tabular}{lllll}
\hline & 0.636 & 0.159 & 0 & \\
\hline & 0.795 & 0.159 & 0 & \\
& 0.755 & 0.159 & 0 & \\
& 0.709 & 0.159 & 0 & \\
$\mathrm{X} 2$ & 0.803 & 0.159 & 0 & Valid \\
& 0.793 & 0.159 & 0 & \\
& 0.734 & 0.159 & 0 & \\
\hline & 0880 & 0.159 & 0 & \\
& 0.896 & 0.159 & 0 & \\
$\mathrm{Y}$ & 0.803 & 0.159 & 0 & Valid \\
& 0833 & 0.159 & 0 &
\end{tabular}

Source: Processed by researchers, 2020

Based on the results of the data above, it can be seen that the validity test values of variables $\mathrm{X} 1, \mathrm{X} 2$, and $\mathrm{Y}$ are declared valid because all Rhitung items are greater than $\mathrm{R}$ table.

Reliability Test

Table 2.The Acquisition of Brand Image Variable Reliability Test Calculation (X1)

\begin{tabular}{ccc}
$\begin{array}{c}\text { Cronbach's } \\
\text { Alpha }\end{array}$ & $\begin{array}{c}\text { Cronbach's Alpha } \\
\text { Based on Standardized } \\
\text { Items }\end{array}$ & $\begin{array}{c}\text { N of } \\
\text { Items }\end{array}$ \\
\hline .861 & .861 & 8 \\
\hline
\end{tabular}

source: Data processed by researchers, 2020

Judging from the reliability test results above, it can be stated that the brand image variable (X1) produces data $0.861>0.6$, so the brand image variable questionnaire can be said to be reliable.

Table 3. Reliability Test of Online Consumer Review Variables (X2)

\begin{tabular}{ccc}
\hline $\begin{array}{c}\text { Cronbach's } \\
\text { Alpha }\end{array}$ & $\begin{array}{c}\text { Cronbach's Alpha } \\
\text { Based on Standardized } \\
\text { Items }\end{array}$ & $\begin{array}{c}\text { N of } \\
\text { Items }\end{array}$ \\
\hline .853 & .859 & 6 \\
\hline
\end{tabular}

Source: Data processed, 2020

The reliability test results on the online consumer review variable can be declared reliable, because the data results show a number of 0.859 which is greater than 0.6 .

Table 4.Results of Consumer Loyalty Variable Reliability Test (Y)

\begin{tabular}{ccc}
\hline $\begin{array}{c}\text { Cronbach's } \\
\text { Alpha }\end{array}$ & $\begin{array}{c}\text { Cronbach's Alpha } \\
\text { Based on Standardized } \\
\text { Items }\end{array}$ & $\begin{array}{c}\text { N of } \\
\text { Items }\end{array}$ \\
\hline .873 & .876 & 4 \\
\hline
\end{tabular}


Source: Data processed by Researchers, 2020

Based on the data above, the reliability test of the consumer loyalty variable shows a result of 0.876 which is greater than 0.6 which can be stated that the data is reliable or factual.

F Test (Simultaneous)

Table 5. Acquisition of F Test Results (Simultaneous) ANOVA $^{\mathrm{a}}$

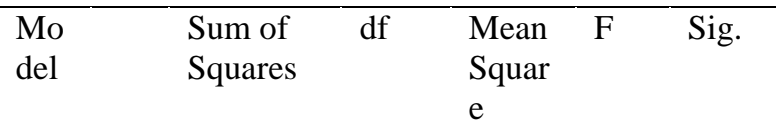

\begin{tabular}{lllllll}
\hline 1 & $\begin{array}{l}\text { Regr } \\
\text { essio }\end{array}$ & 833,553 & 2 & 416,7 & 80, &, \\
& & & 77 & 442 & $000 \mathrm{~b}$ \\
& & & & & & \\
& $\begin{array}{l}\text { Resi } \\
\text { dual }\end{array}$ & 761,620 & 147 & 5,181 & & \\
& & & & & \\
& Tota & 1595,173 & 149 & & & \\
1 & & & & & \\
\hline
\end{tabular}

Source: Data processed by researchers, 2020

It is known that the Ftable value is 3.91 and the Fcount value is 80.442 . when viewed from the results of the value Fcount is greater than Ftable and the sig value. amounting to 0.000 less than 0.05 , it can be stated in accordance with the basis of decision making, namely brand image (X1) and online consumer review (X2) have an effect simultaneously or together with the consumer loyalty variable (Y).

Coefficient of Determination

Table 6 . Results of the coefficient of determination

Model Summary

\begin{tabular}{lllll}
\hline Model & $\mathrm{R}$ & $\begin{array}{l}\mathrm{R} \\
\text { Square }\end{array}$ & $\begin{array}{l}\text { Adjusted } \\
\text { R Square }\end{array}$ & $\begin{array}{l}\text { Std. Error } \\
\text { of the } \\
\text { Estimate }\end{array}$ \\
\hline 1 &, $723^{\text {a }}$ &, 523 &, 516 & 2,27620 \\
\hline
\end{tabular}

Source: Results of data processing by researchers, 2020

Obtaining the results from the above data processing can be stated that the value of the coefficient of determination (R2) in this study is 0.516 , which can be explained that the percentage of the contribution of the brand image variable (X1) and online consumer review (X2) has a value of $51.6 \%$ while the rest that is, $48.4 \%$ is influenced by other factors not examined in this study.

Multiple Linear Regression Analysis and $\mathrm{T}$ Test (Partial)

Table 7. Acquisition of Multiple Linear Regression Results and T Test

\begin{tabular}{|c|c|c|c|c|c|c|}
\hline \multicolumn{7}{|c|}{ Coefficients $^{\mathrm{a}}$} \\
\hline & \multicolumn{3}{|c|}{$\begin{array}{c}\text { Unstandardized } \\
\text { Coefficients }\end{array}$} & \multicolumn{3}{|c|}{$\begin{array}{c}\text { Standardized } \\
\text { Coefficients }\end{array}$} \\
\hline & Todel & B & $\begin{array}{l}\text { Std. } \\
\text { Error }\end{array}$ & Beta & $\mathrm{t}$ & Sig. \\
\hline 1 & $\begin{array}{c}\text { (Con } \\
\text { stant } \\
\text { ) }\end{array}$ & $-3,991$ & 1,492 & & $-2,674$ & , 008 \\
\hline & $\mathrm{X} 1$ &, 267 &, 065 &, 344 & 4,113 &, 000 \\
\hline & $\mathrm{X} 2$ &, 411 &, 080 &, 431 & 5,152 &, 000 \\
\hline
\end{tabular}

Dependent Variable: Consumer loyalty (Y)

Source: Data processed by researchers, 2020

Based on the results of the questionnaire processing using IBM SPSS Software Statistics version 24 which is stated as, the constant value of -3.991 that the coefficient of the consumer loyalty variable is 3.991. The following is the result of the equation value from multiple linear regression analysis $\mathrm{Y}=-3.991+$ $0.267 \mathrm{X} 1+0.411 \mathrm{X} 2$.

The regression coefficient value of variable $\mathrm{X} 1$ is 0.267 , so if the brand image increases by $1 \%$, the value of consumer loyalty increases by 0.267 , the same thing as variable X2 which has a coefficient value of 0.411 , so if online consumer reviews increase by $1 \%$, the value of consumer loyalty also increases 0.411 . and both of these variables contribute positively to the consumer loyalty variable $(\mathrm{Y})$.

Partial testing (T test), the researchers used a significant level of 5\%, and obtained T table of 1.976. The variable brand image (X1) on consumer loyalty (Y) shows the result, the value of Tcount4,113> T table 1,976 with sig. $0.000<0.05$, it can be said that brand image has a positive and significant effect on consumer loyalty.For the online consumer review variable (X2) on consumer loyalty (Y), it is Thitung 5,152> T table 1,976 with sig. $0.000<0.05$, which means that there is a partially significant and positive influence of the online consumer review variable on consumer loyalty.

\section{CONCLUSIONS}

Based on the results of the research, discussion and data analysis techniques that the researchers used in this study regarding brand image and online consumer reviews on consumer loyalty, Nature Republic Aloe vera 92\% soothing gel in Sukabumi City, researchers can draw conclusions, namely the results of tests carried out by testing. T (partial) and also F test (simultaneous), the brand image variable (X1) has a positive effect on the consumer loyalty variable (Y), which means that the first hypothesis is accepted, and the online consumer review variable (X2) has a significant and positive effect on the consumer loyalty variable. which means that the hypothesis is accepted,Also for simultaneous testing (Test $\mathrm{F}$ ) there is a positive and significant effect, namely between the variable brand image and online consumer review on consumer loyalty Nature Republic aloe $92 \%$ soothing gel in Sukabumi City. 
In testing R2 (Coefficient of Determination) produces a value of 0.516 which means that the brand image and online consumer review variables have a value of $51.6 \%$ and the remaining $48.4 \%$ is influenced.48.4\% influenced by other factors not examined in this study.

In this case, the brand image of a company or product is very important for the sustainability of its existence in the market, to be able to give or get consumer confidence in a company or product must have a good image that can be used as a benchmark for consumers to choose or buy a product that can fulfill their desires. as well as the needs of its consumers. And in online consumer reviews, companies must be able to find any mistakes or shortcomings of the products they sell and fix these so that consumers and existing customers do not move to competing companies

\section{REFERENSI}

Angkiriwang, D. I., Susanto, K. C., \& Thio, S. (2018). Pengaruh Ulasan Online di Tripadvisor Terhadap Minat Menginap Generasi Milenial di Surabaya. Jurnal Hospitality Dan Manajemen Jasa, 6(2010), 452-468.

Aryatilandi, S., Ramdan, A. M., \& Surnarya, E. (2020). Analisis Word of Mouth dan Brand Image Terhadap Keputusan Pembelian Smartphone di Kota Sukabumi. Jurnal Manajemen Dan Bisnis Dewantara, 3, 54-65.

Auliya, Z. F., Umam, M. R. K., \& Prastiwi, S. K. (2017). Online Costumer Reviews ( OTRs ) dan Rating: Kekuatan Baru pada Pemasaran Online di Indonesia. Jurnal EBBANK, 8(1), 89-98.

Biron, B. (2019). Beauty Has Blown Up To Be A $\$ 532$ Billion Industry - And Analysts Say That These 4 Trends Will Make It Even Bigger. Www.Businessinsider.Sg.

Cahyono, E. (2018). Pengaruh Citra Merek, Harga dan Promosi Terhadap Keputusan Pembelian Handphone Merek Oppo Di Sleman Daerah Istimewa Yogyakarta. JBMA, V(1), 61-75.

Fajarta, C. R. (2020). BPOM: Nilai Temuan Kosmetik Ilegal Meningkat Drastis. Beritasatu.Com.

Ganyang, M. T. (2019). Pembentukan Loyalitas Pelanggan Melalui Citra merek dan Kualitas Produk. Jurnal Riset Manajemen Dan Bisnis, 4, 781-790.

Kamila, K. T., Suharyono, \& Nuralam, I. P. (2019). Pengaruh Online Consumer Review Terhadap Keputusan Pembelian. Jurnal Administrasi Bisnis (JAB), 72(1), 202-211.

Kanitra, A. R. (2018). Pengaruh Country of Origin dan Online Consumer Review Terhadap Trust dan Keputusan Pembelian. Jurnal Administrasi Bisnis (JAB), 61(1), 64-73.

Kotler, P., \& Keller, kevin lane. (2016). Marketing Management (S. Wall (ed.); 15th ed.). pearson education, inc.

Marie, A. L., \& Widodo, R. E. (2019). Pengaruh Online Reciews Terhadap Online Hotel Booking Intentions, Study kasus pada Traveloka. Jurnal Ilmiah Pariwisata, 24(3), 194-207.

Naturerepublic. (2020). Nature Republic. Brand.Naturerepublic.Com.

Octaviany, A., Norisanti, N., \& Jhoansyah, D. (2019). Determinasi Brand Trust Terhadap Brand Loyality pada House of KAGE Sukabumi. Journal of Economic, Business and Accounting, 3.

Pirdaus, A., Danial, R. deni M., \& Ramdan, A. M. (2020). Analisis Efek Komunitas dan Electronic Word Of Mouth Terhadap Brand Switching Produk Xiaomi Pocophone ke Oppo F9 di RNY Communicatin Kota Sukabumi. Journal of Management and Bussines, $2, \quad 1-8$. https://doi.org/https://doi.org/10.315339/jomb.v2il.1220

Putri, B. rahayu tanama. (2017). Manajemen Pemasaran.

Ramadhan, M. A. F. (2019). Pengaruh Citra Merek, Kepercayaan, dan Komitmen Terhadap Loyalitas Pelanggan Aplikasi Transportasi Online GOJEK di Kota Malang. Jurnal Ilmu Manajemen, 4(September), 153-169.

Ramdan, A. M., Rahayu, A., Hurriyati, R., \& Sultan, M. A. (2020). The Role of Brand Equity in Making Decisions to Choose Higher Education for New Middle - Class Students. Management Science Letters, 2527.

Ramdan, A. M., Rahayu, A., Wibowo, L. A., \& Dirgantari, P. D. (2020). The Effect of Uniqeness and Student's Experience in Improving University Image: Empirical Study at Private Universities in Indonesia. Management Science Letters, 357-364. https://doi.org/10.5267/j.ms1.2020.9.034

Reza, M., Siregar, S., \& Marliyah. (2020). Analisis Loyalitas Konsumen Muslim Terhadap Starbucks Coffee Pasca Dukungan Starbucks Terhadap Lgbt. Jurnal Ekonomi Islam, 5, 1-21.

Rizaldi, M. L., \& Hardini, R. (2018). Pengaruh Kualitas Pelayanan, Brand Image dan Customer Relationship Managementterhadap Loyalitas Pelanggan Indomaret Kelurahan Padurenan, Bekasi Timur. Jurnal Ilmu Manajemen, 14(2), 77-94.

Shahbandeh, M. (2020). Growth Rate of The Global Cosmetics Market 2004 to 2019. Www.Statista.Com. sudaryono. (2016). Manajemen Pemasaran Teori dan Implikasi. C.V ANDI OFFSET.

Tangguh, G. G., Pangestuti, E., \& Nuralam, I. P. (2018). Pengaruh Citra Merek, Kualitas Layanan dan Harga 
Analysis of Brand Image and Online Consumer Reviews on Consumer Loyalty

Lisnawati $^{1}$, Asep Muhamad Ramdan ${ }^{2}$, Dicky Jhoansyah ${ }^{3}$

Terhadap Kepuasan Pelanggan Go-Ride (Survei pada Mahasiswa Fakultas Ilmu Administrasi Universitas Brawijaya Angkatan 2016/2017 dan 2017/2018). Jurnal Administrasi Bisnis, 61(2), 118-126.

Tomida, M., \& Satrio, B. (2016). Pengaruh harga dan Citra Merek Terhadap Loyalitas Pelanggan Produk Footwear Yongki Komaladi. Jurnal Ilmu Dan Riset Manajemen, 5.

Widyawati, N. (2006). Pengaruh Kepercayaan dan Komitmen Serta Bauran Pemasaran Jasa Terhadap Loyalitas Konsumen Di Hotel Zakiah Medan. Jurnal Ekuitas, 12(55), 74-96. 